1 How long do ecosystems take to recover from atmospheric nitrogen deposition?

2 Carly J. Stevens ${ }^{1 *}$

$3{ }^{1}$ Lancaster Environment Centre, Lancaster University, Lancaster, LA1 4YQ, UK.

$4 \quad *$ Corresponding author: C.Stevens@lancaster.ac.uk

\title{
6 Abstract
}

7 Atmospheric nitrogen $(\mathrm{N})$ deposition is a considerable threat to biodiversity and ecosystem function

8 globally. Many experimental $\mathrm{N}$ additions and studies using gradients of ambient deposition have

9 demonstrated impacts on plant species richness, diversity and composition in a broad range of

10 habitats together with changes in soil biogeochemistry. In the last two decades levels of $\mathrm{N}$

11 deposition have begun to decline in some parts of Europe but it is currently difficult to assess the extent to which reductions in $\mathrm{N}$ deposition will result in recovery within semi-natural habitats. There have been a number of investigations using the cessation of $\mathrm{N}$ additions in long-term experiments, monitoring in areas where ambient deposition has declined, transplants to situations with lower $\mathrm{N}$ inputs and roof experiments where rain is collected and cleaned. This review collates evidence from experiments in grasslands, forests, heathlands and wetlands where $\mathrm{N}$ additions have ceased or where $\mathrm{N}$ inputs have been reduced to assess how likely it is that habitats will recover from $\mathrm{N}$ deposition. The results of the majority of studies suggest that vegetation species composition, below-ground communities and soil processes may be slow to recover whereas some soil variables, such as nitrate and ammonium concentrations, can respond relatively rapidly to reductions in $\mathrm{N}$ inputs. There are a number of barriers to recovery such as continued critical load exceedance and lack of seed bank or local seed source, and there is the potential for vegetation communities to reach an alternative stable state where species lost as a consequence of changes due to $\mathrm{N}$ deposition may not be able to recolonise. In these cases only active restoration efforts can restore damaged habitats. 
Keywords: Atmospheric nitrogen deposition, forest, grassland, heathland, recovery, wetland,.

Highlights

- Soil ammonium and nitrate concentrations frequently respond relatively quickly to reduced N

- $\quad$ The response of plant tissue $\mathrm{N}$ concentrations varied between habitats

- Soil processes are often slow to recover from reduced $\mathrm{N}$ inputs

- Vegetation species composition is also often slow to recover from reduced $\mathrm{N}$ inputs.

\section{Introduction}

Global anthropogenic creation of reactive $\mathrm{N}$ increased from approximately $15 \mathrm{Tg} N$ in 1860 to 187 Tg N in 2005 (Galloway et al. 2004). Similar patterns have been observed at a European scale resulting in large changes in fluxes of N. Between 1900 and 2000 atmospheric deposition of N doubled from 1.9 to $3.8 \mathrm{Tg} \mathrm{N}$ per year (Sutton et al. 2011). These increases have been caused by rapid population growth and increases in the per capita usage of N. Globally the creation of reactive $\mathrm{N}$ is continuing to increase (Galloway et al. 2008), but in recent years emission of $\mathrm{N}$ from Europe have seen small declines (Fowler 2007). A wide range of policies have contributed to emission reductions in Europe; a key policy has been the 2008 Directive on Industrial Emissions concerning Integrated Pollution Prevention and Control (IPPC; 2010/75/EU). This directive sets standards for emissions from all industrial combustion sources and requires installations to use best available technology to reduce emissions. This has been complemented by the National Emissions Ceilings Directive (2001/81/EC) which sets upper limits for emissions and the Ambient Air Quality Directive $(2008 / 50 / E C)$ which sets limit values for pollutants as well as a series of protocols including the Gothenburg Protocol. Combined with CAP reform influencing animal numbers and nature conservation policies protecting sites close to point sources emission reductions have been achieved. The impact of these emission reductions has been very variable across Europe (Sutton et 
al. 2011) but the consequence is that some regions, such as parts of the UK and the Netherlands, are beginning to see reductions in deposition of reactive $\mathrm{N}$ with further reductions predicted for the future.

Atmospheric deposition of $\mathrm{N}$ has been reported to have negative impacts on a range of European habitats. Impacts commonly associated with increases in soil $\mathrm{N}$ concentrations and availability of $\mathrm{N}$ (e.g. Phoenix et al. 2012) and reduction in soil pH and consequent impacts on metal availability (Horswill et al. 2008; Jonsson et al. 2003; Stevens et al. 2009). These changes in soils are associated with increases in net primary productivity (e.g. Bobbink et al. 1998; Mountford et al. 1993; Phoenix et al. 2012) and reductions in plant species richness and diversity (e.g. Maskell et al. 2010; Stevens et al. 2010). Other impacts include reductions in the abundance or occurrence of sensitive high and lower plant species (e.g. Bobbink 1991; Henrys et al. 2011; Stevens et al. 2012b; Van den Berg et al. 2011), an increased sensitivity to secondary stressors such as frost (Caporn et al. 2000) and insect herbivores (Brunsting and Heil 1985). Given recent reductions in emissions and the reductions in deposition of reactive $\mathrm{N}$ that are occurring in some regions as a consequence, this raises the question; can semi-natural habitats recover from $\mathrm{N}$ deposition? Recovery from an environmental perturbation can be difficult to define. Reversion to a preexisting state fails to consider natural developments within the system (e.g. succession), other environmental perturbations or changes in management. In a constantly changing environment it is not necessarily realistic to expect an individual site to return to a previous state. Thus in this review how recovery is defined depends to some extent on the methods used. In replicated trials with experimental controls recovery is considered convergence with control plots. In monitoring studies recovery may be judged as similarity to a control site or region or as a significant change in the response variables in the opposite direction to change induced by $\mathrm{N}$ addition or deposition. It is not yet clear whether recovery from $\mathrm{N}$ deposition is possible when traditional management practices continue and there is no active restoration. This manuscript will review existing studies focussed on 
recovery from $\mathrm{N}$ deposition or addition to assess the potential for recovery in terrestrial habitats and explore barriers to recovery.

\section{Methods}

Literature searches were conducted to identify experimental or monitoring studies where habitats were recovering from elevated $\mathrm{N}$ inputs. Literature searches were conducted using Web of Knowledge with the following keywords: 'nitrogen', 'deposition', 'fertil*' (to allow for US and UK spellings of fertiliser), and 'recover*' (to allow for variations on the term recovery). Results were refined to remove studies focussed on freshwater systems by excluding papers with the terms 'river' and 'lake'. Study areas were refined to cover subject areas: biodiversity conservation, environmental science, ecology and forestry. Searches with the terms 'nitrogen deposition recover*' produced 457 records and fertiliser nitrogen recover* resulted in 357 records. These references were refined by reading the titles and abstracts. This removed many studies that were not specifically related to recovery from elevated levels of $\mathrm{N}$ including many where recovery was mentioned but not specifically investigated. The remaining relevant 46 records were added to a marked list. Further searches with the following terms combined with nitrogen deposition identified a further eight relevant papers: cessation of nitrogen, reduction in nitrogen, reduced nitrogen, declining nitrogen, decrease in nitrogen, termination of nitrogen and hysteresis. Papers were read and the selection was further refined to exclude studies that were based purely on modelling or experimental studies where due to the experimental design the effects of and recovery from $\mathrm{N}$ additions could not be separated from those of other nutrient additions, for example where an NPK fertiliser was added. The exception to this was where other nutrients had only been added at very low levels (e.g. to replace hay offtake) so $\mathrm{N}$ was clearly the focus of the study. The other exception was where longterm monitoring saw changes in both $\mathrm{N}$ and sulphur ( $\mathrm{S}$ ) (and potentially other elements) or clean rain experiments removing $\mathrm{N}$ and $\mathrm{S}$ from rainfall. In these cases it was felt that removing these studies would remove too great a proportion of the literature but these studies need to be 
interpreted with this in mind. One study was removed where levels of $\mathrm{N}$ addition were not stated.

References cited in the selected papers but not identified during searches were also incorporated. This resulted in a total of 36 relevant studies which were grouped according to four broad habitat types: grasslands, forests, heathlands and wetlands (Table 1).

Papers were read closely and any measured impacts of reduced $\mathrm{N}$ on plant and soil ecology and biogeochemistry were noted. In $\mathrm{N}$ addition experiments where $\mathrm{N}$ additions were made over a period of time and then ceased variables which did not show a response to the original $\mathrm{N}$ addition were excluded. Unfortunately the small number of studies and variability in experimental design and data collected mean that quantitative meta-analysis was not possible.

With only two exceptions (one study in USA and one in China) the investigations on recovery from $\mathrm{N}$ deposition have taken place in Europe.

Where multiple publications were available from the same experiment all were considered in the collation of data. If the same variable had been measured at different time points then both were noted but only the longer recovery period was used in numbers of studies presented.

\section{Results and Discussion}

\subsection{Approaches to investigating recovery from $\mathrm{N}$ deposition}

A range of approaches have been used to investigate the potential for recovery from $\mathrm{N}$ deposition. The most commonly used approach is the continued monitoring of $\mathrm{N}$ addition experiments after $\mathrm{N}$ additions have ceased (15 out of 26 independent investigations). There is a very large variation in these experiments, not just in habitat and physical conditions at the experimental site but also in the length of time that $\mathrm{N}$ has been applied for, the length of the recovery period, the amount of $\mathrm{N}$ used and the experimental design (Table 1).

An alternative approach has been the use of long-term monitoring. This has taken the form of monitoring of single or multiple sites and comparing changes to ambient deposition (Jonard et al. 2012; Storkey et al. 2015; Vanguelova et al. 2010; Verstraeten et al. 2012) or monitoring following 
the removal of a point source (Armolaitis and Stakenas 2001; Sujetoviene and Stakenas 2007). In these studies it is likely that concentrations and deposition of not only $\mathrm{N}$ but also other pollutants, in particular $\mathrm{S}$, are changing over time too and isolating $\mathrm{N}$ effects directly may be easier with some metrics than others.

Transplants of vegetation or intact cores have also been used to assess recovery from $\mathrm{N}$ deposition. This can involve transplanting cores from polluted environments to less polluted ones (Armitage et al. 2011; Mitchell et al. 2004) or transplanting to mesocosms with $\mathrm{N}$ added artificially (Jones 2005 cited in Emmett 2007).

The final approach that has been used is collecting rainfall using roofs, cleaning rain of $\mathrm{N}$ and then adding clean rain back onto the plots under the roofs. This approach was used in a European network of experiments for the project NITREX where roofs were used to reduce deposition in five forested sites in Sweden, Denmark, Germany and the Netherlands. The NITREX project was primarily concerned with $\mathrm{N}$ saturation and acidification and as such both $\mathrm{N}$ and $\mathrm{S}$ were removed from rain (Wright and van Breeman 1995).

\subsection{Impacts of $N$ reduction in grasslands}

Although there have been some very long-term experiments looking at recovery from fertiliser additions (e.g. Olff and Bakker 1991; Olff et al. 1994; Storkey et al. 2015) relatively few grassland studies have focussed on $\mathrm{N}$ alone. Four studies where $\mathrm{N}$ additions were discontinued were identified in grasslands together with one study where intact cores were transplanted into mesocosms and $\mathrm{N}$ additions made at a lower levels of deposition, one roof experiment where $\mathrm{N}$ was cleaned from precipitation and one long-term monitoring study (Table 1). especially concentrations of soil nitrate and ammonium. At Wardlow Hay Cop $\mathrm{N}$ additions were made to experimental plots at rates of 25,75 and $140 \mathrm{Kg} \mathrm{N} \mathrm{ha}^{-1} \mathrm{yr}^{-1}$ for 11 years. During the treatment period in the acidic grassland soil ammonia concentrations had increased significantly but 
within one year peak concentrations of soil ammonium had fallen and after four years concentrations were not significantly different from untreated controls (O'Sullivan et al. 2011). Similar results were obtained by Stevens et al. (2012a) at Tadham Moor (neutral grassland) who found that 15 years after $\mathrm{N}$ had been applied at rates of $25,50,100,200 \mathrm{Kg} \mathrm{N} \mathrm{ha}^{-1} \mathrm{yr}^{-1}$ for four years only the $100 \mathrm{Kg} \mathrm{N} \mathrm{ha}^{-1} \mathrm{yr}^{-1}$ treatment remained significantly different from the untreated control. Soil nitrate concentration was similarly responsive converging with the control plots at Wardlow Hay Cop acidic and calcareous grassland after two and five years respectively and were found to have recovered at Tadham Moor. Clark et al. (2009) also found recovery in soil nitrate concentrations in a prairie grassland in Minnesota 12 years after the cessation of $\mathrm{N}$ additions at rates of $10,20,34,54$, 95, 170, and $270 \mathrm{Kg} \mathrm{N} \mathrm{ha}^{-1} \mathrm{yr}^{-1}$ for ten years. In the GANE roof experiment reductions in soil nitrate 
years later Ellenberg $\mathrm{N}$ scores were significantly higher than the control plots in all except the lowest treatment ( $25 \mathrm{Kg} \mathrm{N} \mathrm{ha}^{-1} \mathrm{yr}^{-1}$ ) (Stevens et al. 2012a) and diversity was still impacted after 20 years recovery in a prairie grassland (Isbell et al., 2013). Similarly an experiment in northeast China showed species composition differed from control plots in terms of the abundance, identity of dominant species and the abundance of annual species after three years of recovery (following four years treatment with $200 \mathrm{Kg} \mathrm{N} \mathrm{ha}^{-1} \mathrm{yr}^{-1}$ ) (Shi et al. 2014). In a mesocosm experiment where deposition was reduced from $20 \mathrm{Kg} \mathrm{N}^{-1} \mathrm{yr}^{-1}$ to $10 \mathrm{Kg} \mathrm{N} \mathrm{ha}^{-1} \mathrm{yr}^{-1}$ cover of the bryophyte Racomitrium lanuginosum showed no change but it did show signs of recovery when $\mathrm{N}$ inputs were reduced to $0 \mathrm{Kg} \mathrm{N} \mathrm{ha}^{-1} \mathrm{yr}^{-1}$ (Jones 2005 cited in Emmett 2007). In contrast Storkey et al. (2015) found legume proportion increased in line with decreasing deposition, showing rapid signs of recovery in the Park Grass experiment. Both Tadham Moor and the north-eastern Chinese experiment failed to show recovery in species diversity, richness or evenness (Mountford et al. 1993; Shi et al. 2014; Stevens et al. 2012a) although trends for recovery were again observed at the Park grass experiment (Storkey et al. 2015). Despite lack of recovery in species composition, two experiments have shown recovery in biomass and vegetation height (Mountford et al. 1993; Shi et al. 2014; Stevens et al. 2012a).

\subsection{Impacts of $N$ reduction in forests}

There have been a number of long-term investigations looking at the impact of $\mathrm{N}$ reduction in forest habitats. Primary amongst these investigations is the NITREX project which investigated reduced deposition at five sites using roofs (Wright and van Breeman 1995). Additionally there have been four studies published based on long-term monitoring of forested sites, four experiments where $\mathrm{N}$ additions have been ceased and one study of epiphytic lichens that used reciprocal transplant (Table 1). The majority of studies have been in coniferous forests ( 9 coniferous, 1 broadleaved and 2 multi-site investigations with both broadleaf and coniferous forests). 

or addition have typically seen responses in relatively short time periods. Three of the NITREX experimental sites (Ysselsteyn, Speuld, Solling) where $\mathrm{N}$ deposition was reduced from ambient levels to background levels using roofs with rain collected and cleaned of $\mathrm{N}$ and $\mathrm{S}$, have reported on reductions in soil ammonium concentration. All three sites found significant reductions in both surface and deeper soil horizons within three years (Boxman et al. 1995; Boxman et al. 1994; Bredemeier et al. 1995; Koopmans et al. 1995). Armolaitis and Stakenas (2001) found that eleven years after a fertiliser plant reduced emissions of mineral fertiliser dust, $\mathrm{CO}, \mathrm{SO}_{2}, \mathrm{NO}_{\mathrm{x}}$ and $\mathrm{NH}_{3}$ mineral soil horizons showed ammonium concentrations downwind of the plant that were not significantly different from control plots. Long-term monitoring in France between 1978 and 2007 in a Norway Spruce forest also showed significant reductions in ammonium concentration as ambient $\mathrm{N}$ deposition fell (Jonard et al. 2012). However, two monitoring networks (UK and Belgium) showed no change as a result of reductions in ambient deposition: Vanguelova et al. (2010) found no significant differences in ammonium concentrations at sites where there had been reductions in rainfall $\mathrm{N}$ in both shallow and deep soil and Verstraeten et al. (2012) only found significant reductions at one of five sites. Soil nitrate concentrations results were very similar with reductions reported from experimental manipulations (Boxman et al. 1994; Bredemeier et al. 1995; Koopmans et al. 1995) but mixed results from monitoring (Jonard et al. 2012; Vanguelova et al. 2010; Verstraeten et al. 2012).

The roof experiments and monitoring following the closure of the fertiliser plant all reported increases in soil pH and at the Solling roof experiment acid neutralising capacity also increased (Armolaitis and Stakenas 2001; Bredemeier et al. 1995; Martinson et al. 2005) but it should be noted that in all of these investigations $\mathrm{S}$ was reduced as well as $\mathrm{N}$.

Soil process measurements seem to show less signs of recovery. At three of the NITREX sites decomposition was measured and showed no significant difference under roofs compared to ambient controls after between two and four years (Boxman et al. 1995; Boxman et al. 1998b) and 
$\mathrm{N}_{2} \mathrm{O}$ measurements were not reduced after seven years at the Solling site (Borken et al. 2002). After ten years slight increases in mineralisation, immobilization and ammonium and microbial pool turnover rates were observed (Corre and Lamersdorf, 2004). Gross N mineralisation was investigated in a Norway Spruce forest 17 and 19 years after 20 years of $N$ addition at a rate of 73 and $108 \mathrm{Kg} \mathrm{N} \mathrm{ha}^{-1} \mathrm{yr}^{-1}$ respectively and no difference from control plots was observed (Blasko et al. 2013).

A small number of investigations have looked at the impact of $\mathrm{N}$ reduction on soil ecology.

Although processes may remain impacted for many years the microbial community shows very variable results between investigations. Mycorrhizal diversity and number of fruiting bodies were found to have significantly increased after four years at one of the Netherlands NITREX sites, although mycorrhizal root density had not recovered (Boxman et al. 1995; Jones 2005 cited in Emmett et al. 1998). However, in a long-term $\mathrm{N}$ addition and recovery experiment, Strengbom et al.

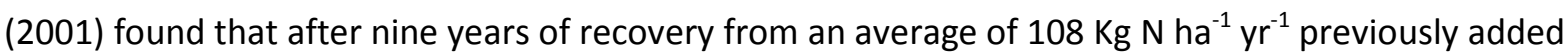
for 28 years in a Norway spruce forest, mycorrhizal fruiting body abundance and composition remaining significantly different from untreated controls, and in a Scots pine forest treated with an average of $103 \mathrm{Kg} \mathrm{N} \mathrm{ha}^{-1} \mathrm{yr}^{-1}$ for 14 years and allowed to recover for 48 years, mycorrhizal fruiting body abundance was also significantly lower than the control. In contrast, after 15 years of recovery in the Norway spruce experimental site ectomycorrhizal sequences showed no difference to the untreated control plots. However, bacterial markers showed a significantly different species composition to controls and the fungal:bacterial ratio was also significantly different (Högberg et al. 2014). It is difficult to conclude that the additional six years had permitted recovery in the mycorrhizal community since different measures were used but these results suggest that this may be the case. Sixteen years of reduced acid inputs in the Solling roof experiment resulted in no difference in substrate induced respiration, 16S rRNA genes in the soil profile, and densities of nitrate reducer and denitifier genes. Nitrate reductase activity was significantly reduced in autumn but not in spring. 

have taken place in coniferous systems and thus have focussed on concentrations in needles. In the NITREX experiments one site showed a reduction in needle $\mathrm{N}$ but three sites showed no significant difference (Boxman et al. 1998a; Boxman et al. 1995; Boxman et al. 1998b; Bredemeier et al. 1998) although measurements at one site suggested a lag of three years (Boxman et al. 1998b). Long-term monitoring in France also showed no change in needle $\mathrm{N}$ concentration as deposition declined (Jonard et al. 2012). Reductions were observed in a pine forest in Sweden fifteen years after the cessation of experimental additions (Högberg et al. 2011). Needle concentrations of other elements ( $\mathrm{K}, \mathrm{Ca}, \mathrm{Mg}$ ) have also tended not to change (Boxman et al. 1995; Bredemeier et al. 1998) although concentrations of argenine were responsive (Boxman et al. 1995; Boxman et al. 1998b). Tree stem wood production was found to be reduced compared to controls after 19 years of recovery following $108 \mathrm{Kg} \mathrm{N} \mathrm{ha}^{-1} \mathrm{yr}^{-1}$ added for 20 years (Blasko et al. 2013), but one NITREX experimental site was found to be showing improvements in diameter growth after four years (Boxman et al. 1998b). Root growth and biomass also showed signs of recovery at NITREX experimental sites (Boxman et al. 1998a; Boxman et al. 1995; Bredemeier et al. 1998; Persson et al. 1998). Results for productivity of ground flora are not reported but investigations looking at species composition, richness and diversity have failed to find signs of recovery (Boxman et al. 1995; Strengbom et al. 2001; Sujetoviene and Stakenas 2007), even with up to 48 years since last N addition (Strengbom et al. 2001). Armolaitis and Stakenas (2001) found improvements in Ellenberg $\mathrm{N}, \mathrm{R}$ and $\mathrm{L}$ scores following large reductions in emissions from a fertiliser plant. One study has investigated the impact of reductions in epiphyte growth and found species specific responses with one species (Frullania tamarisci) responding positively to being moved to a lower $\mathrm{N}$ deposition site whilst another showed no change (Isothecium myosuroides) (Mitchell et al. 2004). 

heathlands (Table 1). Following seven years of $\mathrm{N}$ additions at rates of 7.7 and $15.4 \mathrm{Kg} \mathrm{N} \mathrm{ha}^{-1} \mathrm{yr}^{-1}$ and eight years of recovery time Power et al. (2006) showed strong signs of recovery in lowland heathland with soil extractable $\mathrm{N}$, total $\mathrm{N}$, microbial biomass $\mathrm{N}$ and $\mathrm{pH}$ all showing no significant difference from untreated controls. The only reported soil variable that still showed an impact of $\mathrm{N}$ was dehydrogenase activity. In contrast Edmondson et al. (2013) found no recovery of peat total N with $\mathrm{N}$ additions of $10,20,40$ and $120 \mathrm{Kg} \mathrm{N} \mathrm{ha}^{-1} \mathrm{yr}^{-1}$ for five years followed by seven years of recovery. These soil results were reflected in litter $\mathrm{N}$ concentrations which only showed reductions in $\mathrm{NH}_{4}{ }^{+}$and $\mathrm{NO}_{3}{ }^{-}$at the highest $\mathrm{N}$ addition level and total $\mathrm{N}$ only showed recovery in the $40 \mathrm{Kg} \mathrm{N} \mathrm{ha}{ }^{-1}$ $\mathrm{yr}^{-1}$ treatment.

Edmondson et al. (2013) also found that vegetation had recovered little from $\mathrm{N}$ additions.

After seven years of recovery Calluna vulgaris height, density and shoot extension were all significantly different from untreated controls. Lichen frequency, bryophyte diversity and frequency also showed no signs of recovery. After eight years of recovery Power et al. (2006) found that $C$. vulgaris cover and shoot growth were not significantly different to controls plots but height was still significantly greater and earlier bud burst was observed in the previously $\mathrm{N}$ treated plots. Negative effects of the $\mathrm{N}$ treatments were still apparent in lichen frequency. Experiments in Svalbard in two areas of dwarf shrub heath dominated by Dryas octopetala or Cassiope tetragona received 10 and $50 \mathrm{Kg} \mathrm{N} \mathrm{ha}^{-1} \mathrm{yr}^{-1}$ for eight and three years respectively with recovery for 18 and 13 years. Both of these experiments showed species composition significantly different to untreated controls and in the $C$. tetragona dominated heathland lichen cover remained significantly different too. Whilst $\mathrm{N}$ concentrations in shrub tissues showed no significant difference from untreated controls, levels in bryophytes remained elevated (Street et al. 2015).

In a reciprocal transplant experiment where turfs of $R$. lanuginosum were relocated from sites with deposition between 8.2 and $32.9 \mathrm{Kg} \mathrm{N} \mathrm{ha}^{-1} \mathrm{yr}^{-1}$ to a site with $7.2 \mathrm{Kg} \mathrm{N} \mathrm{ha}^{-1} \mathrm{yr}^{-1}$ cover and depth of 
significantly higher than the controls. Transplanted shoots grew $35 \%$ less than controls but $25 \%$ less than indigenous $R$. lanuginosum so showed some signs of acclimatisation. Concentrations of $\mathrm{N}$ in tissues also showed signs of recovery but did not reach levels of $R$. lanuginosum native to the site (Armitage et al. 2011).

\subsection{Impacts of $N$ reduction in wetlands}

There have been a very small number of investigations investigating recovery from $\mathrm{N}$ additions in wetlands (Table 1).

In the Italian dolomites Gerdol and Brancaleoni (2015) made additions of 10 and $30 \mathrm{Kg} \mathrm{N}^{-1}$ $\mathrm{yr}^{-1}$ to a transitional mire for eight years. After three years without $\mathrm{N}$ additions species composition showed little sign of recovery with the abundance of key species, including Sphagnum fuscum, showing ongoing effects. In a rich fen where $200 \mathrm{Kg} \mathrm{N} \mathrm{ha}^{-1} \mathrm{yr}^{-1}$ was added once and then recovery was permitted for seven years some variables, including below-ground biomass, were also slow to recover (El-Kahloun et al. 2003). Above-ground biomass N:P also showed no signs of recovery (ElKahloun et al. 2003) although in contrast, Limpens and Heijmans (2008) found that within 15 months Sphagnum capitulum tissue $\mathrm{N}$ concentration and $\mathrm{N}: \mathrm{P}$ ratio recovered from three years of $40 \mathrm{Kg} \mathrm{N}$ ha ${ }^{1} \mathrm{yr}^{-1}$.

\subsection{Which habitats and variables are most likely to recover?}

All of the habitats reviewed have examples of where the impacts of low levels of $\mathrm{N}$ addition (i.e. within the range of ambient $\mathrm{N}$ deposition) or ambient levels of deposition have persisted for in excess of three years so it can reasonably be assumed that complete and very rapid recovery is unlikely. Understanding in wetlands is limited by a lack of investigations and across habitats many $\mathrm{N}$ cessation experiments have used high levels of $\mathrm{N}$ addition making it difficult to relate them to $\mathrm{N}$ deposition impacts but in grasslands and heathlands there are examples where effects of low levels 
of $\mathrm{N}$ addition have been observed for fifteen years or more after cessation. This suggests that even medium-term recovery may not be possible for all variables.

Within each habitat there is a very large range of habitat variation, soils, climate and timespans of $\mathrm{N}$ addition and recovery encompassed in the results summarised here which makes meta-analysis of the data impractical given the number of data points available, however it is possible to summarise which groups of variables respond most often and assess their functional significance.

Soil chemistry variables have commonly been recorded in the investigations summarised here.

In a majority of cases mobile or plant-available forms of $\mathrm{N}$ show signs of recovery (12 out of 14 investigations for at least one measured variable), in many cases this is a relatively rapid response even where levels of $\mathrm{N}$ were previously high. Results are relatively consistent across habitats but, although this can be taken as a good sign of recovery, without tracer studies it is impossible to identify whether mobile $\mathrm{N}$ in recovering ecosystems has the same fate as $\mathrm{N}$ in un-impacted ecosystems. Potential mechanisms for recovery include removal of $\mathrm{N}$ by plant uptake and biomass removal, denitrification in wet habitats, microbial immobilisation and loss of $\mathrm{N}$ from the habitat by leaching or runoff. Total $\mathrm{N}$ less commonly showed signs of recovery suggesting that $\mathrm{N}$ can be stored in less readily biologically accessible pools for long time periods. This $\mathrm{N}$ could potentially be released in the future if site conditions change. Relatively few studies have considered changes in process based measurements such as decomposition and mineralisation but those that have indicate that these processes may take longer to recover. Clark et al. (2009) noted that even small amounts of $N$ retention may influence internal cycling long after inputs cease and it seems like these processes could potentially take many decades to recover. The lack of recovery observed in soil processes is potentially very important because they can lead to broader ecosystem impacts, positive feedbacks and impacts on other parts of the $\mathrm{N}$ cycle. Changes in soil biology are possibly closely related to functional processes. There has been very little research but based on the studies that have 
investigated this in forests it seems likely that there could be medium to long-term impacts on mycorrhizal and bacterial communities. This is an area in need of further research.

The concentrations and stoichiometric balance of nutrients plant tissues seem to respond relatively rapidly to reductions in $\mathrm{N}$ inputs with most investigations in heathlands (4 out of 5 investigations for at least one measured variable) and grasslands ( 4 out of 5 investigations for at least one measured variable)showing responses within a few years. It has previously been recognised that tissue $\mathrm{N}$ content is a relatively plastic trait that can respond rapidly to increases in deposition (Dise and Wright 1995) through reduced luxury uptake and storage but in forests needle concentrations failed to respond as rapidly to decreases in $\mathrm{N}$ addition (5 out of 6 studies for at least one measured variable). Species composition and richness generally seem to be slow to recover with some long-term investigations still showing differences after a decade or more (e.g. Stevens et al. 2012a; Street et al. 2015; Strengbom et al. 2001). This is not the case for all long-term investigations, Storkey et al. (2015) reported changes in species composition of control plots of the Park Grass experiment which could be correlated with changes in $\mathrm{N}$ deposition. They also saw good recovery in plots where fertiliser additions had been discontinued but since there were no treatments for $\mathrm{N}$ alone these are not considered here. Management of the grassland with cutting and removal of may be have played an important role in the recovery observed in the Park Grass experiment. Removal of $\mathrm{N}$, either through active management or natural processes (denitrification, leaching or runoff), has the potential to promote recovery reducing biologically available pools of N. Options for on-site management to restore habitats are discussed in Jones et al. (this issue).

It seems likely that habitats where active management is in place involving $\mathrm{N}$ removal are most likely to recover from $\mathrm{N}$ deposition together with those where vegetation is adapted to higher nutrient levels. These would also be the habitats where the magnitude of $\mathrm{N}$ impacts are likely to be smaller.

\subsection{Barriers to recovery}



hysteresis in the recovery of many ecosystem responses. There may be delays of a few years up to many decades and more long-term experiments are needed to provide reliable estimates of recovery times. Some variables are more likely to respond positively to reductions in $\mathrm{N}$ inputs but based on the investigations reviewed here it seems unlikely that all aspects of the system can recover in short timescales. The actual speed of recovery is likely to depend on a wide range of factors including habitat, soil and hydrological conditions, deposition history and the extent of the reduction and landscape context but currently, there are too few investigations to draw out conditions most likely to be conducive to recovery. We can however, identify potential barriers to recovery. to recovery and may be one reason that some published investigations have shown slow or no recovery. Critical loads are defined as "the level below which significant harmful effects on specified sensitive elements of the environment do not occur" (Nilsson and Grennfelt 1988). This means that if, despite reductions in $\mathrm{N}$ additions, the critical load is still exceeded damage is likely to still be occurring, $\mathrm{N}$ may still be accumulating in the habitat albeit at a lower rate, or recovery may not occur. Where $\mathrm{N}$ inputs have been particularly high, such as close to a point source, or have occurred for long periods of time, we might also expect to see slower recovery than for smaller $\mathrm{N}$ inputs and short exposures. In such situations we would expect to see greater storage of $\mathrm{N}$ within the soil and larger changes to the ecosystem. Unfortunately, in many parts of Europe critical loads have been exceeded for several decades, and in some habitats and locations by large margins which may make recovery without active restoration challenging. composition. Not only might a lack of recovery in the below-ground community or processing of $\mathrm{N}$ 410 lead to continued elevated soil $\mathrm{N}$ pools, but plant species which have declined in response to elevated $\mathrm{N}$ may not be well represented in the seed bank whereas species from pioneer and weedy 
communities may have abundant and persistent seed banks (Bakker and Berendse 1999). The availability of a seed source for species that have declined may be another obstacle to recolonisation

414 (Bakker and Berendse 1999), especially as impacts of $\mathrm{N}$ deposition are likely to occur over large areas.

As vegetation species composition changes this has implications for the broader ecosystem and the changes in community composition arising from $\mathrm{N}$ deposition could lead to a community with very different traits to the desired community. This could include impacts on the below-ground community and nutrient cycling (Suding et al. 2004) with implications for the potential for recovery. It is also possible that we could see alternative stable states as a consequence of elevated $\mathrm{N}$ deposition. Alternative stable states can occur when a system shifts to another state and is reinforced by positive feedbacks such as the return of nutrient rich litter causing elevated mineralisation rates, or internal conditions (Suding et al. 2004). In response to $\mathrm{N}$ addition this could occur when competitive species increase as a component of vegetation impacted by $\mathrm{N}$ deposition (Bobbink et al. 2010). Many of these species, such as competitive grasses, may need elevated $\mathrm{N}$ to become established within a typically low-nutrient community. This creates a situation where the less competitive species are unable to compete sufficiently to re-establish themselves or become dominant again. Furthermore, changes in other factors such as climate or other pollutants could all cause changes in the vegetation that make recovery less likely (Suding et al. 2004). potential for recovery from $\mathrm{N}$ deposition. The heather beetle caused extensive damage to heathlands in the Netherlands in response to elevated $\mathrm{N}$ deposition leading to a change in vegetation from domination by C. vulgaris to domination by grasses (Heil and Diemont 1983). With the level of vegetation change caused by the combination of $\mathrm{N}$ deposition and heather beetle (Lochmaea suturalis) attacks, over large areas, the potential for recovery without active restoration was very low. 


\section{Conclusion}

It is clear from a range of investigative approaches that whilst some soil variables, such as nitrate and ammonium concentrations, can respond relatively rapidly to reductions in $\mathrm{N}$ inputs, other variables such as total $\mathrm{N}$ concentration and processes such as mineralisation and decomposition may take longer to recover. Soil fungal and bacterial communities have shown mixed results in the few studies that have measured them. Above-ground plant tissue $\mathrm{N}$ concentrations seem to respond relatively rapidly to reductions in most habitats (grassland, heathland and wetland) but investigations in coniferous forests suggest that there may be a lag in recovery of needle $\mathrm{N}$ concentrations. Vegetation species composition was slow to respond in the majority of studies that investigated it (8 out of 9 for at least one of the measured variables). Given these findings it is reasonable to suggest that recovery from $\mathrm{N}$ deposition is likely to be a slow process. Many results are from short-term investigations, continuation of these investigations is vital to provide estimates of recovery time for slower responding variables and to provide realistic recovery rates. deposition and raise the question whether semi-natural habitats can recover completely from $\mathrm{N}$ deposition without active restoration? Further research is needed to determine whether complete recovery is possible and whether there are particular site conditions or deposition histories which promote or hinder recovery. Most urgently research is needed into the potential for soil processes and soil communities to recover from $\mathrm{N}$ addition.

457

\section{Acknowledgements} version of this manuscript.

\section{References}


Armitage, H.F., Britton, A.J., Woodin, S.J., van der Wal, R., 2011. Assessing the recovery potential of alpine moss-sedge heath: Reciprocal transplants along a nitrogen deposition gradient. Environ Pollut. 159, 140-147.

Armolaitis, K., Stakenas, V., 2001. The recovery of damaged pine forests in an area formerly polluted by nitrogen. The Sci World. 1, 384-393. grassland. New Phytol. 180, 864-874.

Bakker, J.P., Berendse, F., 1999. Constraints in the restoration of ecological diversity in grassland and heathland communities. Trends Ecol and Evol. 14, 63-68.

Beier, C., Blanck, K., Bredemeier, M., Lamersdorf, N., Rasnussen, L., Xu, Y.-J., 1998. Field-scale 'clean rain' treatments to two Norway spruce stands within the EXMAN project- effects on soil solution chemistry, foliar nutrition and tree growth. Forest Ecol Manag. 101, 111-123. Blasko, R., Hogberg, P., Bach, L.H., Hogberg, M.N., 2013. Relations among soil microbial community composition, nitrogen turnover, and tree growth in $\mathrm{N}$-loaded and previously $\mathrm{N}$-loaded boreal spruce forest. Forest Ecol Manag. 302, 319-328.

Bobbink, R., 1991. Effects of nutrient enrichment in Dutch chalk grassland. J Appl Ecol. 28, 28-41. Pardo, L., De Vries, W., 2010. Global assessment of nitrogen deposition effects on terrestrial plant diversity: a synthesis. Ecol Appl. 20, 30-59.

Bobbink, R., Hornung, M., Roelofs, J.G.M., 1998. The effects of air-borne nitrogen pollutants on species diversity in natural and semi-natural European vegetation. J Ecol. 86, 717-738. proton inputs did not affect atmospheric methane uptake and nitrous oxide emission from a German spruce forest soil. Soil Biology and Biochemsitry 34, 1815-1819. 

Persson, H., Timmermann, V., 1998a. Vegetation and soil biota response to experimentally-changed nitrogen inputs in coniferous forest ecosystems of the NITREX project. Forest Ecology and Management 101, 65-79.

493

Boxman, A.W., van Dam, D., van Dijk, H.F.G., Hogerorst, R.F., Koopmans, C.J., 1995. Ecosystem

responses to reduced nitrogen and sulphur inputs into two coniferous forest stands in the nitrogen input to a Scots pine stand at Ysselsteyn, the Netherlands. Forest Ecology and Management $101,155-163$.

Boxman, A.W., van Dijk, H.F.G., Roelofs, J.G.M., 1994. Soil and vegetation responses to decreased atmospheric nitrogen and sulphur inputs into a Scots pine stand in the Netherlands. Forest Ecology and Management 68, 39-45.

502 Bredemeier, M., Blanck, K., Lamersdorf, N., Wiedey, G.A., 1995. Response of soil water chemistry to experimental 'clean rain' in the NITREX roof experiment at Solling, Germany. Forest Ecology and Management 71, 31-44. Ecology and Management 101, 57-64.

Branderud, T.E., Timmermann, V. 1998. Ectomycorrhizal fungi in the NITREX site at Gkdsjiin, Sweden; below and above-ground responses to experimentally-changed nitrogen inputs 1990-1995. Forest

510 Ecology and Management 101, 207-214.

511 Brunsting, A.M.H., Heil, G.W., 1985. The role of nutrients in the interactions between a herbivorous

512 beetle and some competing plant species in heathlands. Oikos 44, 23-26.

513 Caporn, S.J.M., Ashenden, T.W., Lee, J.A., 2000. The effect of exposure to $\mathrm{NO}_{2}$ and $\mathrm{SO}_{2}$ on frost hardiness in Calluna vulgaris. Environmental and Experimental Botany 43, 111-119. 

years after treatments cease despite minimal long-term nitrogen retention. Global Change Biology $15,1755-1766$.

Dise, N.B., Wright, R.F., 1995. Nitrogen leaching from European forests in relation to nitrogen deposition. Forest Ecology and Management 71, 153-161. pollution in heather moorlands: Ecosystem response to simulated decline in nitrogen deposition over seven years. Science of the Total Environment 444, 138-144. below-ground rich fen vegetation following fertilization. Journal of Vegetation Science 14, 451-458. Emmett, B., 2007. Nitrogen saturation of terrestrial ecosystems: some recent findings and their implications for our conceptual framework. Water Air and Soil Pollution Focus 7, 99-109.

Emmett, B.A., Boxman, A.W., Bredemeier, M., Gundersen, P., Kjonaas, O.J., Moldan, F., Schleppi, P., Tietema, A., Wright, R.F., 1998. Predicting the effects of atmospheric nitrogen deposition in conifer stands: evidence from the NITREX ecosystem-scale experiments. Ecosystems 1, 352-360. Fowler, D., 2007. Long term trends in sulphur and nitrogen deposition in Europe and the cause of non-linearities. Water Air and Soil Pollution: Focus 7, 41-47. Cleveland, C.C., Green, P.A., Holland, E.A., Karl, D.M., Michaels, A.F., Porter, J.H., Townsend, A.R., Vorosmarty, C.J., 2004. Nitrogen cycles: past, present, and future. Biogeochemistry 70, 153-226. Galloway, J.N., Townsend, A.R., Erisman, J.W., Bekunda, M., Cai, Z., Freney, J.R., Martinelli, L.A., Seitzinger, S.P., Sutton, M.A., 2008. Transformation of the nitrogen cycle: Recent trends, questions 537 and potential solutions. Science 320, 889-892.

538 Gerdol, R., Brancaleoni, L., 2015. Slow recovery of mire vegetation from environmental 539 perturbations caused by a heat wave and experimental fertilization. Wetlands $35,769-782$. 
Heil, G.W., Diemont, W.H., 1983. Raised nutrient levels change heathland into grassland. Vegetatio $53,113-120$.

Henrys, P., Stevens, C.J., Smart, S.M., Maskell, L.C., Walker, K., Preston, C.D., Crowe, A., Rowe, E.,

Gowing, D.J., Emmett, B.A., 2011. Using national data archives to detect nitrogen impacts on vegetation in the UK. Biogeosciences 8, 3501-3518. after termination of decadal nitrogen additions to boreal forest. Soil Biology and Biochemsitry 72, $35-43$.

Högberg, P., Johannisson, C., Yarwood, S., Callesen, I., Nasholm, T., Myrold, D.D., Hogberg, M.N., 2011. Recovery of ectomycorrhiza after 'nitrogen saturation' of a conifer forest. New Phytologist $189,515-525$.

Horswill, P., O’Sullivan, O., Phoenix, G.K., Lee, J.A., Leake, J.R., 2008. Base cation depletion, eutrophication and acidification of species-rich grasslands in response to long-term simulated nitrogen deposition. Environmental Pollution 155, 336-349. Isbell, F., Tilman, D., Polasky, S., Binder, S., Hawthorn, P. 2013. Low biodiversity state persists two decades after cessation of nutrient enrichment. Ecology Letters 16, 454-460. Jonard, M., Legout, A., Nicolas, M., Dambrine, E., Nys, C., Ulrich, E., van der Perre, R., Ponette, Q., 2012. Deterioration of Norway spruce vitality despite a sharp decline in acid deposition: a long-term integrated perspective. Global Change Biology 18, 711-725. Jones, L., Stevens, C., Rowe, E.C., Payne, R., Caporn, S.J.M., Evans, C.D., Field, C., Dale, S. This issue.

560 Can on-site management mitigate nitrogen deposition impacts? Biological Conservation.

561 Jonsson, U., Rosengren, U., Thelin, G., Nihlgard, B., 2003. Acidification-induced chemical changes in 562 coniferous forest soils in southern Sweden 1988-1999. Environmental Pollution 123, 75-83.

563 Kandler, E., Brune, T., Enowashu, E., Dörr, N., Guggenberger, G., Lamersdorf, N., Philippot, L., 2008. Response of total and nitrate-dissimilating bacteria to reduced $\mathrm{N}$ deposition in a spruce forest soil profile. Federation of European Microbiological Societies Microbial Ecology 67, 444-454. 

saturated forest ecosystems subjected to an experimental decrease in nitrogen deposition. Plant and Soil $175,205-218$.

Limpens, J., Heijmans, M.M.P.D., 2008. Swift recovery of Sphagnum nutrient concentrations after excess supply. Oecologia 157, 153-161.

Martinson, L., Lamersdorf, N., Warfvinge, P., 2005. The Solling roof revisited - slow recovery from acidification observed and modeled despite a decade of "clean-rain" treatment. Environmental Pollution 135, 293-302.

Maskell, L.C., Smart, S.M., Bullock, J.M., Thompson, K., Stevens, C.J., 2010. Nitrogen Deposition causes widespread species loss in British Habitats. Global Change Biology 16, 671-679. Growth and tissue nitrogen of epiphytic Atlantic bryophytes: effects of increased and decreased atmospheric $\mathrm{N}$ deposition. Functional Ecology 18, 322-329. Mountford, J.O., Lakhani, K.H., Kirkham, F.W., 1993. Experimental assessment of the effects of nitrogen addition under hay-cutting and aftermath grazing on the vegetation of meadows on a Somerset peat moor. Journal of Applied Ecology 30, 321-332. Nilsson, J., Grennfelt, P.E., 1988. Critical Loads for sulphur and nitrogen. UNECE/Nordic Council of Ministers, Copenhagen, Denmark. in species-rich grasslands after 12 years of simulated pollutant nitrogen deposition: a 6-year experimental analysis. Global Change Biology 17, 2615-2628.

587 Olff, H., Bakker, J.P., 1991. Long-term dynamics of standing crop and species composition after the cessation of fertiliser application to mown grassland. Journal of Applied Ecology 28, 1040-1052.

589 Olff, H., Berendse, F., Devisser, W., 1994. Changes in nitrogen mineralization, tissue nutrient concentrations and biomass compartmentation after cessation of fertilizer application to mown grassland. Journal of Ecology 83, 611-620. 
Persson, H., Ahlstrom, K., Clemensson-Lindell, A., 1998. Nitrogen addition and removal at Gardsjon effects on fine-root growth and fine-root chemistry. Forest Ecology and Management 101, 199-205. Phoenix, G.K., Emmett, B.A., Britton, A.J., Caporn, S.J.M., Dise, N.B., Helliwell, R., Jones, L., Leake, J.R., Leith, I.D., Sheppard, L.J., Sowerby, A., Pilkington, M.G., Rowe, E.C., Ashmore, M.R., Power, S.A., 2012. Impacts of atmospheric nitrogen deposition: responses of multiple plant and soil parameters across contrasting ecosystems in long-term field experiments. Global Change Biology 18, 1197-1215. Power, S.A., Green, E.R., Barker, C.G., Bell, J.N.B., Ashmore, M.R., 2006. Ecosystem recovery: heathland response to a reduction in nitrogen deposition. Global Change Biology 12, 1241-1252. Shi, S., Yu, Z., Zhao, Q., 2014. Responses of plant diversity and species composition to the cessation of fertilization in a sandy grassland. Journal of Forestry Research 25, 337-342.

Stevens, C.J., Dise, N.B., Gowing, D.J., 2009. Regional trends in soil acidification and metal mobilisation related to acid deposition. Environmental Pollution 157, 313-319.

Stevens, C.J., Duprè, C., Dorland, E., Gaudnik, C., Gowing, D.J.G., Bleeker, A., Diekmann, M., Alard, D., Bobbink, R., Fowler, D., Corcket, E., Mountford, J.O., Vandvik, V., Aarrestad, P.A., Muller, S., Dise, N.B., 2010. Nitrogen deposition threatens species richness of grasslands across Europe. Environmental Pollution 158, 2940-2945.

Stevens, C.J., Mountford, J.O., Bardgett, R.D., Gowing, C.J., 2012a. Differences in yield, Ellenberg N value, tissue chemistry and soil chemistry 15 years after the cessation of nitrogen addition. Plant and Soil 357, 309-319.

Stevens, C.J., Smart, S.M., Henrys, P., Maskell, L.C., Crowe, A., Simkin, J., Walker, K., Preston, C.D., Cheffings, C., Whitfield, C., Rowe, E., Gowing, D.J., Emmett, B.A., 2012b. Terricolous lichens as indicators of nitrogen deposition: Evidence from national records. Ecological Indicators 20, 196-203. Storkey, J., Macdonald, A.J., Poulton, P.R., Scott, T., Kohler, I.H., Schnyder, H., Goulding, K.W.T., Crawley, M.J., 2015. Grassland biodiversity bounces back from long-term nitrogen addition. Nature $528,401-404$. 
Street, L.E., Burns, N.R., Woodin, S.J., 2015. Slow recovery of High Arctic heath communities from nitrogen enrichment. New Phytologist 206, 682-695. Strengbom, J., Nordin, A., Nasholm, T., Ericson, L., 2001. Slow recovery of boreal forest ecosystem following decreased nitrogen input. Functional Ecology 15, 451-457. Suding, K.N., Goss, K.L., Houseman, G.R., 2004. Alternative states and positive feedbacks in restoration ecology. Trends in Ecology and Evolution 19, 46-53. Sujetoviene, G., Stakenas, V., 2007. Changes in understaory vegetation of Scots pine stands under the decreased impact of acidifying and eutrophying pollutants. Baltic Forestry 13, 190-196. Sutton, M.A., Howard, C.M., Erisman, J.W., Billen, G., Bleeker, A., Grennfelt, P., Van Grinsven, H., Grizzetti, B. eds., 2011. The European Nitrogen Assessment: Sources, effects and policy perspectives. Cambridge University Press, Cambridge. Van den Berg, L.J.L., Vergeer, P., Rich, T.C.G., Smart, S.M., Guest, D., Ashmore, M.R., 2011. Direct and indirect effects of nitrogen deposition on species composition change in calcareous grasslands. Global Change Biology 17, 1871-1883. Vanguelova, E.I., Bareham, S., Pitman, R., Moffat, A.J., Broadmeadow, M., Nisbet, T., Durrant, D., Barsoum, N., Wilkinson, M., Bochereau, F., Hutchigs, T., Broadmeadow, S., Crow, P., Taylor, P., Durrant Houston, T., 2010. Chemical fluxes in time through forest ecosystems in the UK - Soil response to pollution recovery. Environmental Pollution 158, 1857-1869. atmospheric deposition on forest soil solution chemistry in Flanders, Belgium. Atmospheric Environment 62, 50-63. roof project: The impact of reduced N \& S deposition and experimental warming in an acid grassland. Water, Air and Soil Pollution: Focus 4, 187-196.

641 Wright, R.F., van Breeman, N., 1995. The NITREX project: an introduction. Forest Ecology and 
Table 1. Studies on different aspects of ecosystem recovery from nitrogen deposition included in this review: a) 'Cessation of $\mathrm{N}$ Addition' studies are classed as those that have added additional $\mathrm{N}$ for a time period and then ceased additions, b) 'Monitoring' refers to studies without experimental manipulation that monitor conditions in relation to amient $\mathrm{N}$ deposition, c) 'Roof Studies' refer to investigations where roofs have been used to collect rain which is then cleaned of $\mathrm{N}$ and added back beneath the roof, and d) 'Transplants' refer to investigations where samples or intact cores have

\begin{tabular}{|c|c|c|c|c|c|}
\hline $\begin{array}{l}\text { a) Cessation of } \mathrm{N} \text { addition } \\
\text { Source }\end{array}$ & Country & Habitat & $\begin{array}{l}\mathrm{N} \text { addition } \\
\text { rate } \\
\left(\mathrm{Kg} \mathrm{N} \mathrm{ha}^{-1} \mathrm{yr}^{-1}\right)\end{array}$ & $\begin{array}{l}\text { Years of } \\
\mathbf{N} \\
\text { addition }\end{array}$ & $\begin{array}{l}\text { Years of } \\
\text { recovery }\end{array}$ \\
\hline $\begin{array}{l}\text { Arroniz-Crespo et al. } 2008 \\
\text { O’Sullivan et al. } 2011\end{array}$ & UK & $\begin{array}{l}\text { Acidic Grassland } \\
\text { Acidic and } \\
\text { Calcareous } \\
\text { grassland }\end{array}$ & $\begin{array}{l}35,140 \\
35,75,140\end{array}$ & 11 & $\begin{array}{l}1.8 \\
5\end{array}$ \\
\hline Edmondson et al., 2013 & UK & Heathland & $10,20,40,120$ & 5 & 7 \\
\hline $\begin{array}{l}\text { Clark et al., } 2009 \\
\text { Isbell et al., } 2013\end{array}$ & USA & Prairie grassland & $\begin{array}{l}10,20,34,54 \\
95,170,270\end{array}$ & 10 & $\begin{array}{l}12 \\
20\end{array}$ \\
\hline Shi et al. 2014 & China & Grassland & 200 & 4 & 3 \\
\hline Mountford et al. 1996 & UK & Grassland & $\begin{array}{l}25,50,100 \\
200\end{array}$ & 4 & 4 \\
\hline Stevens et al. 2012 & & & & & 15 \\
\hline Street et al. 2015 & Svalbard & $\begin{array}{l}\text { Cassiope } \\
\text { tetragona heath } \\
\text { Dryas octopetala } \\
\text { heath }\end{array}$ & $\begin{array}{l}10,50 \\
10,50\end{array}$ & $\begin{array}{l}3 \\
8\end{array}$ & $\begin{array}{l}18 \\
13\end{array}$ \\
\hline Power et al. 2006 & UK & Heathland & $7.7,15.4$ & 7 & 8 \\
\hline Strengbom et al. 2001 & Sweden & $\begin{array}{l}\text { Norway spruce } \\
\text { forest } \\
\text { Scots pine forest }\end{array}$ & $\begin{array}{l}108 \\
103\end{array}$ & $\begin{array}{l}28 \\
14\end{array}$ & $\begin{array}{l}9 \\
48\end{array}$ \\
\hline $\begin{array}{l}\text { Högberg et al. } 2011 \\
\text { Högberg et al. } 2014\end{array}$ & Sweden & Scots pine forest & 110 & 20 & 14 \\
\hline Blasko et al. 2013 & Sweden & $\begin{array}{l}\text { Norway Spruce } \\
\text { Forest }\end{array}$ & 73,108 & 20 & 17,19 \\
\hline
\end{tabular}




\begin{tabular}{|c|c|c|c|c|c|}
\hline $\begin{array}{l}\text { El-Kahloun et al. } 2003 \\
\text { Gerdol and Brancaleoni } \\
2015\end{array}$ & $\begin{array}{l}\text { Belgium } \\
\text { Italy }\end{array}$ & $\begin{array}{l}\text { Rich fen } \\
\text { Mire }\end{array}$ & $\begin{array}{l}200 \\
10,30\end{array}$ & $\begin{array}{l}1 \\
8\end{array}$ & $\begin{array}{l}7 \\
3\end{array}$ \\
\hline \multirow{2}{*}{$\begin{array}{l}\text { Limpens and Heijmans } \\
2008\end{array}$} & Netherlands & Poor fen & 40 & 3 & 1.25 \\
\hline & & Rich fen & 40 & 3 & 1.25 \\
\hline \multicolumn{6}{|l|}{ b) Monitoring } \\
\hline Source & Country & Habitat & No. Sites & \multicolumn{2}{|c|}{ Years of monitoring } \\
\hline Storkey et al. 2015 & UK & Neutral grassland & 1 & \multicolumn{2}{|c|}{$1903-2012$} \\
\hline $\begin{array}{l}\text { Armolaitis and Stakenas } \\
2001 \\
\text { Sujetoviene and Stakenas } \\
2007\end{array}$ & Lithuania & Scots pine forest & 1 & \multicolumn{2}{|c|}{$\begin{array}{l}\text { Distance from point } \\
\text { source }\end{array}$} \\
\hline Jonard et al., 2012 & France & $\begin{array}{l}\text { Norway spruce } \\
\text { forest }\end{array}$ & 1 & \multicolumn{2}{|c|}{ 1978-1987 1998-2007 } \\
\hline Vanguelova et al. 2010 & UK & Forest & 11 & \multicolumn{2}{|c|}{$1995-2007$} \\
\hline Verstraeten et al. 2012 & Belgium & Forest & 5 & \multicolumn{2}{|c|}{$1994-2010$} \\
\hline \multicolumn{6}{|l|}{ c) Roof studies } \\
\hline Source & Country & Habitat & Site & \multicolumn{2}{|c|}{ Years of recovery } \\
\hline Williams et al., 2004 & UK & Acid grassland & $\begin{array}{l}\text { Plynlimon } \\
\text { Fawr }\end{array}$ & \multicolumn{2}{|l|}{$<1$} \\
\hline Boxman et al. 1998a & Europe & 4 Forest sites & $\begin{array}{l}\text { NITREX } \\
\text { network }\end{array}$ & \multicolumn{2}{|c|}{$2-4$} \\
\hline Bredemeier et al. 1998 & Europe & 3 Forest sites & $\begin{array}{l}\text { NITREX } \\
\text { network }\end{array}$ & \multicolumn{2}{|c|}{$2-4$} \\
\hline Beier et al. 1998 & Europe & $\begin{array}{l}2 \text { Noeway spruce } \\
\text { forests }\end{array}$ & $\begin{array}{l}\text { EXMAN } \\
\text { project }\end{array}$ & \multicolumn{2}{|c|}{$4-8$} \\
\hline Borken et al. 2002 & Germany & $\begin{array}{l}\text { Norway spruce } \\
\text { forest }\end{array}$ & Solling & \multicolumn{2}{|l|}{7} \\
\hline Bredemeier et al. 1995 & Germany & $\begin{array}{l}\text { Norway spruce } \\
\text { forest }\end{array}$ & Solling & \multicolumn{2}{|c|}{1.5} \\
\hline $\begin{array}{l}\text { Corre and Lamersdorf, } \\
2004\end{array}$ & Germany & $\begin{array}{l}\text { Norway spruce } \\
\text { forest }\end{array}$ & Solling & \multicolumn{2}{|l|}{10} \\
\hline Martinson et al. 2005 & Germany & $\begin{array}{l}\text { Norway spruce } \\
\text { forest }\end{array}$ & Solling & \multicolumn{2}{|l|}{10} \\
\hline Kandler et al., 2008 & Germany & $\begin{array}{l}\text { Norway spruce } \\
\text { forest }\end{array}$ & Solling & \multicolumn{2}{|l|}{16} \\
\hline \multirow[t]{2}{*}{ Boxman et al. 1995} & Netherlands & Douglas Fir forest & Speuld & \multicolumn{2}{|l|}{3} \\
\hline & Netherlands & Scots pine forest & Ysselsteyn & \multicolumn{2}{|l|}{3} \\
\hline \multirow[t]{2}{*}{ Koopmans et al. 1995} & Netherlands & Douglas Fir forest & Speuld & \multicolumn{2}{|l|}{3} \\
\hline & Netherlands & Scots pine forest & Ysselsteyn & \multicolumn{2}{|l|}{3} \\
\hline Boxman et al. 1994 & Netherlands & Scots pine forest & Ysselsteyn & \multicolumn{2}{|l|}{3} \\
\hline Persson et al. 1998 & Sweden & $\begin{array}{l}\text { Norway spruce } \\
\text { forest }\end{array}$ & Gårdsjön & \multicolumn{2}{|l|}{2} \\
\hline Brandrud and & Sweden & Norway spruce & Gårdsjön & \multicolumn{2}{|l|}{5} \\
\hline
\end{tabular}




\begin{tabular}{|c|c|c|c|c|c|}
\hline \multicolumn{2}{|l|}{ Timmermann, 1998} & \multicolumn{4}{|l|}{ forest } \\
\hline \multicolumn{6}{|l|}{ d) Transplants } \\
\hline Source & Country & Habitat & Method & $\begin{array}{l}\text { Start } N \\
\text { rate }(\mathrm{Kg} \mathrm{N} \\
\left.\mathrm{ha}^{-1} \mathrm{yr}^{-1}\right)\end{array}$ & $\begin{array}{l}\text { End } \mathrm{N} \\
\text { rate }(\mathrm{Kg} \mathrm{N} \\
\left.\mathrm{ha}^{-1} \mathrm{yr}^{-1}\right)\end{array}$ \\
\hline $\begin{array}{l}\text { Jones } 2005 \text { cited in } \\
\text { Emmett } 2007\end{array}$ & UK & Acidic grassland & $\begin{array}{l}\text { Mesocosms } \\
\text { with misting }\end{array}$ & 20 & 10,0 \\
\hline Armitage et al. 2011 & UK & Alpine heathland & $\begin{array}{l}\text { Reciprocal } \\
\text { transplant }\end{array}$ & $8.2-32.9$ & 7.2 \\
\hline Mitchell et al. 2004 & UK & $\begin{array}{l}\text { Atlantic Oak } \\
\text { woodland }\end{array}$ & $\begin{array}{l}\text { Reciprocal } \\
\text { transplant }\end{array}$ & 54 & 12 \\
\hline
\end{tabular}

654 